\title{
Model Pendidikan Inklusif Berbasis Authentic Instructional Model Pada Anak Usia Dini
}

\author{
Fuad Aminur Rahman ${ }^{1}$, Acep Awaludin ${ }^{2}$ \\ ${ }^{1}$ SMAN 1 Cihara, Kabupaten Lebak, Provinsi Banten \\ ${ }^{2}$ SMAN 1 Cihara, Kabupaten Lebak, Provinsi Banten
}

\begin{abstract}
Writing articles about the model of inclusive education in early childhood is very necessary This is done to provide references or solutions for schools that provide inclusive education, especially in early childhood education. Therefore here the author is interested in offering a reference or solution about the development of inclusive instructional models based on authentic instructional models in early childhood, namely the inclusive education model that tries to provide an overview in combining the principles of access to education for all students or disadvantaged individuals, and not only for those with special needs. Therefore, the nature of the inclusive education model is a shift from theories, assumptions, practices, and special models of disabilities to the specific non-disability inclusive education system.
\end{abstract}

DOI : https://doi.org/10.15642/jeced.v2i2.573

\section{Article Info}

Article history:

Received: April 13, 2020

Approved: December 28, 2020

Published online: December 31, 2020

Keywords:

inclusive education,

authentic instructional model, early

childhood.

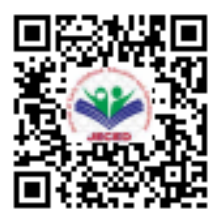

\begin{abstract}
Abstrak
Penulisan artikel tentang model pendidikan inklusif pada anak usia dini sangatlah perlu dilakukan. Hal ini dilakukan untuk memberikan rujukan ataupun solusi bagi sekolah yang menyelenggarakan pendidikan inklusif, khususnya dalam pendidikan anak usia dini. Oleh karenanya disini penulis tertarik untuk menawarkan rujukan atapun solusi tentang pengembangan model pendidikan inklusif berbasis authentic instructional model pada anak usia dini, yakni model pendidikan inklusif yang mencoba untuk memberikan gambaran dalam menggabungkan prinsip akses pendidikan untuk semua pelajar ataupun individu yang kurang beruntung, dan tidak hanya untuk mereka yang berkebutuhan khusus. Oleh karena itu, hakikat model pendidikan inklusif ini merupakan pergeseran dari teori, asumsi, praktik, dan model khusus disabilitas ke sistem pendidikan inklusif yang bersifat spesifik non-disabilitas.
\end{abstract}

\section{Informasi Artikel \\ Riwayat Artikel}

Diterima: 13042020

Disetujui: 28122020

Publikasi online: 31122020

\section{Kata kunci:}

pendidikan inklusif,

authentic instructional model, anak usia dini 


\section{PENDAHULUAN}

Model pendidikan dalam pendidikan inklusif sangatlah diperlukan, hal tersebut mampu memberikan rujukan ataupun alternatif bagi guru pembimbing khusus atau biasa disebut dengan GPK dalam melaksanakan tugasnya di satuan pendidikan inklusifnya. Pada skala internasional bahwa penyelenggaraan pendidikan di setiap tempat harus didasarkan serta dibangun berdasarkan pada perspektif yang bersifat menyeluruh yakni pendidikan bagi semua individu tanpa melihat kondisi individu yang dialami. Munculah berbagai kebijakan terkhusus pemerintah Indonesia yang memberikan wajah dalam pergeseran wujud pendidikan terlebih untuk anak-anak berkebutuhan khusus (Fernandes, R, 2017: 119). Perspektif tersebut tentu menitikberatkan serta menggambarkan secara umum dan lengkap tentang visi serta misi tentang penyelenggaraan, pemerataan dalam proses pendidikan yang terbuka dan bersifat demokratis.

Pendidikan dapat diartikan sebagai hak asasi paling dasar bagi seluruh manusia dimanapun tanpa terkecuali (Indrawati, 2013: 68). Pernyataan itu tentu memberikan pengetahuan dan pandangan bahwa semua individu tanpa melihat kondisi yang dimiliki, memiliki hak atas pendidikan. Pemahaman tersebut kemudian menciptakan atensi bagi dunia pendidikan khusunya sistem pendidikan bagi Anak yang Berkebutuhan Khusus (ABK). Lebih lanjut dinyatakan bahwa anak-anak dengan kebutuhan pendidikan khusus harus memiliki akses ke sekolah reguler yang harus mengakomodasi mereka dalam hal pedagogi yang berpusat pada anak sehingga mampu memenuhi kebutuhan ini.

Pelaksanaan strategi visi serta misi pendidikan bagi semua di Indonesia, dihadirkan melalui berbagai penyusunan aturan berbadan hukum yang perlu diterapkan dalam hal konteks penyamaan dan pemerataan hak-hak pendidikan bagi semua warga negara Indonesia, termasuk warga negara Indonesia yang berkebutuhan khusus. Oleh karenanya langkah-langkah teknis yang dilakukan serta dilaksanakan oleh Pemerintah Republik Indonesia adalah dengan menyelenggarakan proses Pendidikan Inklusif bagi ABK berdasarkan Permendiknas No. 70 tahun 2009 sementara itu terkhusus di Provinsi Banten, diejawantahkan dalam penyusunan kebijakan yakni dengan menerbitkan Peraturan Gubernur Banten Nomor 74 Tahun 2014 tentang Pedoman Penyelenggaraan Pendidikan Inklusif di Provinsi Banten.

Berangkat dari realita di lapangan menunjukkan bahwa masih adanya beberapa sekolah ataupun lembaga pendidikan yang belum memberikan fasilitas ataupun pelayanan khususnya dalam pendidikan inklusif yang optimal bagi anak berkebutuhan khusus (ABK), hal ini tentu didukung berdasarkan data hasil penelitian yang dilakukan oleh Stiawati, T Listyaningsih \& Aziizi (2017) yang menyatakan bahwa implementasi pelaksanaan pendidikan inklusif yang dilakukan oleh Dindikbud Kota Serang dalam melaksanakan Pendidikan Inklusif masih belum terlaksana dengan optimal.

Data diatas pun diperkuat berdasarkan penelitian menunjukkan bahwa GPK masih bertugas seperti guru pada umumnya seperti halnya yakni dengan melaksanakan kegiatan seperti halnya guru kelas, ada yang terpaksa menjadi GPK, hanya karena sekolah kekurangan GPK. Sehingga hal tadi bisa memberikan efek yang kurang baik bagi sekolah yang melaksanakan pendidikan inklusif (Zakia, D, 2015: 13). Dalam pelaksanaannya pun masih ditemukan bahwa anak berkebutuhan khusus masih mendapatkan stigma sebagai penghambat dalam kelancaran pelaksanaan program di kelas, guru kelas pun masih belum mampu memfasilitasi kebutuhan ABK secara baik.

Berdasarkan pemaparan diatas menunjukkan bahwa pelaksanaan implementasi pendidikan inklusif masih perlu untuk diperbaiki menjadi lebih baik, oleh karenanya disini penulis tertarik untuk menuangkan gagasan ataupun ide agar pendidikan inklusif di Indonesia dapat dilaksanakan dengan optimal dan berkualitas yakni melalui "Model Pendidikan Inklusif Berbasis Authentic Instructional Model" yakni model pendidikan inklusif yang mencoba untuk memberikan gambaran dalam menggabungkan prinsip akses pendidikan untuk semua pelajar ataupun individu yang kurang beruntung, dan tidak hanya untuk mereka yang berkebutuhan khusus. Oleh karena 
itu, hakikat model pendidikan inklusif ini merupakan pergeseran dari teori, asumsi, praktik, dan model khusus disabilitas ke sistem pendidikan inklusif yang bersifat spesifik non-disabilitas.

\section{METODE}

Penelitian yang dilakukan merupakan penelitian kualitatif yang dilakukan melalui studi literatur yang bertujuan untuk menganalisis permasalahan yang dihadapi serta dilakukan untuk mendesain dan merancang solusi yang diberikan. Studi literatur dilakukan untuk memberikan penguatan terhadap masalah yang diangkat dalam penulisan ini. Penelitian yang menggunakan studi literatur, didukung menjadi sumber informasi lengkap bagi penelitian kualitatif (SavinBaden, M., \& Howell-Major, 2013).

Instrumen yang digunakan adalah studi dokumentasi yakni dengan mendokumentasikan jurnal, buku, prosiding yang berasal dari google scholar, ataupun dokumen lain yang terkait untuk mengembangkan penulisan dalam publikasi ilmiah. Berdasarkan studi literatur pada tinjauan pustaka dibentuklah pertanyaan penelitian yaitu 1). Apa yang dimaksud dengan hakikat model pendidikan inklusif berbasis authentic instructional model dan 2). Bagaimana implementasi model pendidikan inklusif berbasis authentic instructional model. Data yang telah didapatkan maka dilakukan kompulasi, analisis dan konklusi.

\section{HASIL PENELITIAN DAN ANALISIS}

Hakikat Model Pendidikan Inklusif Berbasis Authentic Instructional Model Bagi Anak Usia Dini

Salah satu syarat keberhasilan dalam proses pendidikan inklusif pada anak usia dini diantaranya adalah peran profesional dari seorang Guru Pembimbing Khusus (GPK), yakni guru yang memiliki tugas untuk mendampingi di sekolah yang menyelenggarakan sistem pendidikan inklusif serta memiliki kompetensi dalam menangani peserta didik yang berkebutuhan khusus. Hal tersebut selaras dengan pernyataan dari Scott (2010: 78) bahwa "the success of the inclusive education depends, to a large extent, on the willingness and the ability of teachers to make accommodations for individuals with special needs". Mengartikan bahwa keberhasilan dalam proses penyelenggaraan pendidikan inklusif tergantung pada besarnya keinginan juga kemampuan yang dimiliki guru pembimbing khusus dalam mengakomodasi kebutuhan individu yang bekebutuhan khusus.

Melalui model pendidikan inklusif yang dilakukan pada pendidikan anak usia dini, anak dapat dibimbing dan diarahkan oleh gurunya dengan strategi, metode dan model yang jelas. Anak dapat bermain dan menyalurkan energi positifnya melalui berbagai kegiatan fisik, musik, atau keterampilan lainnya juga dapat belajar berinteraksi secara interpersonal dan intrapersonal dan sosial (Bhakti, Safitri \& Rahman, 2018: 28).

Pendapat diatas juga diperkuat oleh Wati (2014: 86) yang menyatakan bahwa prinsip dasar pendidikan inklusi adalah memberikan akomodasi kebutuhan yang layak kepada semua anak untuk dapat belajar bersama-sama serta tanpa adanya diskriminasi dalam proses yang diselenggarakan. Berdasarkan asumsi tersebut menunjukkan bahwa perbedaan individu adalah sumber daya untuk proses pendidikan, sehingga pendidikan inklusif mengasumsikan bahwa perspektif pedagogis berpusat pada pembelajar individu

Mittler (2012, p. 12) menyatakan bahwa proses belajar yang dilakukan dalam pendidikan inklusif di sekolah dapat dilihat sebagai salah satu ekspresi dari perjuangan untuk mencapai hak asasi manusia secara universal. Karena pendidikan inklusif merupakan prioritas global, dan di mana PBB telah memberikan kepemimpinannya untuk menjalankan pendidikan inklusif secara global.

Oleh karenanya pendidikan inklusif dimaksudkan sebagai salah satu fitur utama dalam pengembangan kemampuan sistem pendidikan reguler untuk memenuhi kebutuhan pendidikan 
anak-anak dengan segala jenis gangguan. Serta merupakan upaya untuk memberikan kesempatan yang seluasnya serta memberikan jaminan berupa hak pendidikan kepada setiap anak yang berkebutuhan khusus (ABK).

Sementara itu berdasarkan South African Education White Paper 6: Special Needs Education (Juli, 2011), pendidikan inklusif mencakup hal-hal berikut:

- Mengakui bahwa semua anak dan remaja dapat belajar, dan bahwa semua anak dan remaja perlu dukungan dari semua pihak

- Menerima dan menghargai bahwa semua peserta didik berbeda dalam beberapa hal dan memiliki kebutuhan belajar yang berbeda namun tetap memiliki nilai yang sama

- Kapasitasi struktur pendidikan, sistem dan metodologi pembelajaran untuk memenuhi kebutuhan semua peserta didik

- Mengakui dan menghormati perbedaan di antara peserta didik, apakah karena usia, jenis kelamin, etnis, bahasa, kelas, kecacatan atau status HIV

- Mengakui bahwa pembelajaran lebih luas daripada sekolah formal, dan mungkin juga terjadi di rumah dan masyarakat, dan dalam mode dan struktur formal dan informal

- Mengubah sikap, perilaku, metodologi pengajaran, kurikulum dan lingkungan untuk memenuhi kebutuhan semua peserta didik

- Memaksimalkan partisipasi semua peserta didik dalam budaya dan kurikulum lembaga pendidikan

- Mengungkap dan meminimalkan hambatan untuk belajar

- Memberdayakan peserta didik untuk berpartisipasi secara kritis dalam proses pembelajaran dengan mengembangkan kekuatan individu mereka yang sejalan dengan pandangan ini.

Oleh karenanya hakikat dalam model pendidikan inklusif berbasis authentic instructional model ini mencoba untuk memberikan gambaran dalam menggabungkan prinsip akses pendidikan untuk semua pelajar ataupun individu yang kurang beruntung, dan tidak hanya untuk mereka yang berkebutuhan khusus. Oleh karena itu, hakikat model pendidikan inklusif ini merupakan pergeseran dari teori, asumsi, praktik, dan model khusus disabilitas ke sistem pendidikan inklusif yang bersifat spesifik non-disabilitas. Akibatnya, proses pelaksanaan pendidikan inklusif akan menjadi lebih efektif dan relevan, sehingga mampu memberikan luaran dengan memenuhi kebutuhan semua peserta didik, termasuk didalamnya mereka yang berkebutuhan khsusus.

\section{PEMBAHASAN}

\section{Implementasi Model Pendidikan Inklusif Berbasis Authentic Instructional Model Bagi Anak Usia Dini}

Anak yang berkebutuhan khusus (ABK) terlebih anak usia dini perlu mendapatkan hak pendidikan sebagaimana teman seusianya ataupun sebayanya. Oleh karena itu, elemen utama dari pendidikan inklusif adalah menghilangkan hambatan yang menghambat proses pembelajaran dan keaktifan semua anak selama pembelajaran mereka di sekolah, yang bertujuan untuk memaksimalkan potensi setiap individu untuk berkembang secara holistik. Meskipun sudah adanya beberapa sekolah inklusif yang ada di Indonesia, akan tetapi berangkat daripada realita di lapangan bahwa masih adanya sekolah inklusif yang belum matang untuk menyelenggarakan pendidikan inklusif tersebut. Hal tesebut didukung berdasarkan data yang dilansir oleh www.solopos.com pada 21 Juni 2015 menyatakan bahwa sekolah dasar di Kota Yogyakarta, menyatakan bahwa terdapat 60 siswa yang berkebutuhan khusus, sedangkan guru pembimbing khusus yang dimiliki oleh sekolah dasar tersebut hanyalah satu, dan guru tersebut hanya datang dua kali dalam seminggu. Hal tersebut menjadikan indikasi bahwa pelaksanaan pendidikan inklusif di sekolah dasar tersebut belum berjalan dengan baik

Hasil penelitian dari Ni'matuzahroh (2015) juga menyatakan bahwa adanya beberapa kendala yang dihadapi dalam proses penyelenggaraan kelas inklusif seperti halnya adanya 
pemahaman terhadap kurikulum yang berbeda, kurangnya sarana dan prasarana yang dimiliki, pengetahuan tentang inklusif yang minim, adanya penolakan keberadaan beberapa siswa yang berkebutuhan khusus, adanya penolakan peserta didik yang reguler untuk belajar bersama dengan peserta didik yang berkebutuhan khusus, serta pengetahuan guru yang minim tentang cara memberikan pelayanan yang baik kepada anak berkebutuhan khusus di kelas reguler

Oleh karenanya kurangnya pemahaman dan pengetahuan tentang kejelasan konseptual dan kurangnya konvergensi pada pelaksanaan proses pendidikan inklusif telah menyebabkan tujuan dan/atau strategi yang saling bertentangan. Beberapa anak merasa bahwa mereka 'ditinggalkan' dan tidak pernah masuk sekolah atau masuk hanya selama beberapa tahun dan, sebagai pengulang, menjadi 'putus sekolah' atau, lebih tepatnya seperti 'didorong untuk keluar', tanpa adanya kebutuhan mereka yang terpenuhi.

Ilustrasi dibawah ini adalah ilustrasi nyata tentang kegagalan sekolah untuk mengajar daripada kegagalan siswa untuk belajar. Sistem sekolah yang menekankan Pendidikan untuk semua harus memastikan hak semua anak untuk mendapatkan pendidikan yang bermakna berdasarkan kebutuhan dan kemampuan individu (Johnson, 2012, p. 17)

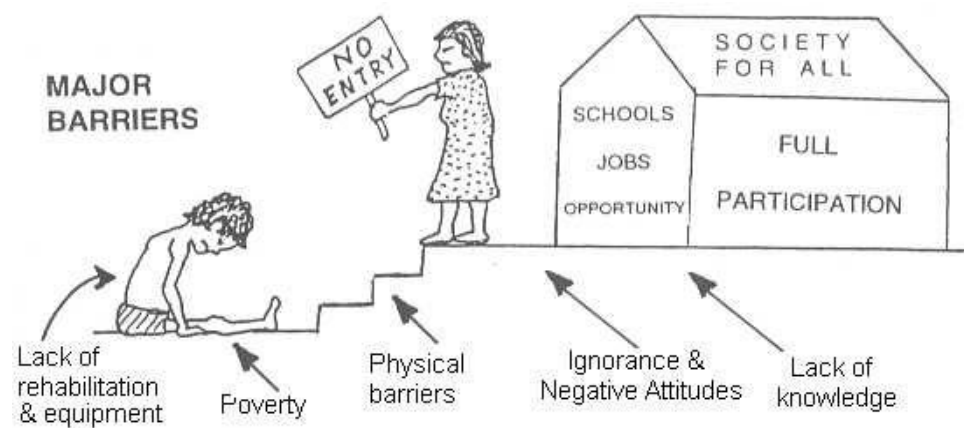

Gambar 1. Ilustrasi Masalah Pendidikan Inklusif

Oleh karena itu dengan adanya pelaksanaan proses pendidikan Inklusif, sekolah reguler sekarang akan semakin memainkan peran utama dan sangat penting dalam memberikan ketersediaan pelayanan untuk anak-anak dengan kebutuhan pendidikan khusus yang harus tersedia dan dilaksanakan secara optimal. Hal ini mungkin mengarah pada perlunya mereformasi sistem sekolah secara keseluruhan dari yang tradisional, berorientasi pada ujian hingga kepada yang inklusif, yakni lebih berorientasi kepada anak. Maka, pengembangan model pendidikan inklusfi berbasis authentic intsructional model ini menjadi hal yang begitu diperlukan dalam pengembangannya karena dalam model ini mencoba untuk memberikan gambaran dalam menggabungkan prinsip akses pendidikan untuk semua pelajar ataupun individu yang kurang beruntung, dan tidak hanya untuk mereka yang berkebutuhan khusus. Berikut adalah tabel yang membedakan antara pendekatan pendidikan bersifat tradisional dengan model pendidikan inklusif berbasis authentic instructional model (Tichá, et al, 2019, p 39): 
Tabel 1. Perbedaan Pendekatan Pendidikan Bersifat Tradisional dengan Model Pendidikan Inklusif Berbasis Authentic Instructional Model

\begin{tabular}{|c|c|}
\hline Pendekatan Tradisional & $\begin{array}{c}\text { Pendekatan Pendidikan Inklusif berbasis } \\
\text { Authentic Instructional Model }\end{array}$ \\
\hline Pendidikan Tradisional & Pendidikan Inklusif \\
Pendidikan untuk Sebagian & Pendidikan untuk Semua \\
Statis & Fleksibel \\
Pengajaran Kolektif & Pengajaran Individual \\
Belajar Secara Terpisah & Belajar Secara Terintegrasi \\
Penekanan Pada Pengajaran & Penekanan Pada Pembelajaran \\
Subjek Terpusat & Anak Terpusat \\
Diagnostik/Preskriptif & Holistik \\
Peluang Dibatasi oleh Pengecualian & Peluang Untuk Semua \\
\hline
\end{tabular}

Model pendidikan inklusif berbasis authentic instructional model ini mengharuskan untuk menanggapi semua siswa sebagai individu, mengakui individualitas sebagai sesuatu yang harus dihargai serta dihormati. Model pendidikan inklusif berbasis authentic instructional model ini mencoba untuk menanggapi serta memenuhi kebutuhan khusus bagi setiap anak, dengan demikian hal tersebut akan memberikan nilai dan makna positif untuk semua murid.

Jika, model pendidikan inklusif berbasis authentic instructional model ini dapat dilaksanakan dengan langkah yang tepat dan terukur, maka akan memberikan dampak yang baik dalam proses penyelenggaraan pendidikan inklusif di sekolah reguler terlebih bagi anak usia dini. Pernyataan diatas diperkuat berdasarkan penelitian yang dilakukan oleh Windarsih dkk (2017: 7) yang menyatakan bahwa jika sistem pembelajaran yang diberlakukan dalam pendidikan inklusif mengakomodasi perbedaan kebutuhan belajar setiap anak usia dini, maka tujuan akhir dari semua upaya dalam implementasi pendidikan inklusif bagi anak usia dini yaitu kesejahteraan para penyandang disabilitas dalam memperoleh segala haknya sebagai warga negara dapat direalisasikan secara optimal.

Diperkuat juga dari hasi penelitian yang dilakukan oleh Alfina \& Anwar (2020: 45) menyatakan bahwa terdapat tiga hal penunjang yang perlu disiapkan untuk menunjang keberhasilan proses model pendidikan inklusif bagi anak usia dini yakni guru (brainware), pengembangan kurikulum (software), serta sarana dan prasarana (hardware). Ketiganya perlu manajemen untuk bisa menciptakan lingkungan belajar yang bisa mendukung perkembangan anak.

Model pendidikan inklusif juga merupakan suatu pendekatan pendidikan yang bersifat inovatif dan strategis dalam melebarkan akses hak pendidikan bagi semua anak difabel termasuk anak usia dini. Juga sebagai bentuk reformasi pendidikan yang menekankan sikap anti diskriminasi, akses pendidikan bagi semua, peningkatan mutu pendidikan, serta upaya mengubah sikap dan stigma masyarakat terhadap anak difabel (Junanto, S., \& Kusna, N. A. A, 2018: 174). Sehingga ketika model pendidikan inklusif berbasis authentic instructional model bagi anak usia dini dapat dilakukan dengan baik maka akan terciptanya tujuan yang tercapai, seperti yang diilustrasikan dibawah ini (Johnson, 2012: 18) 


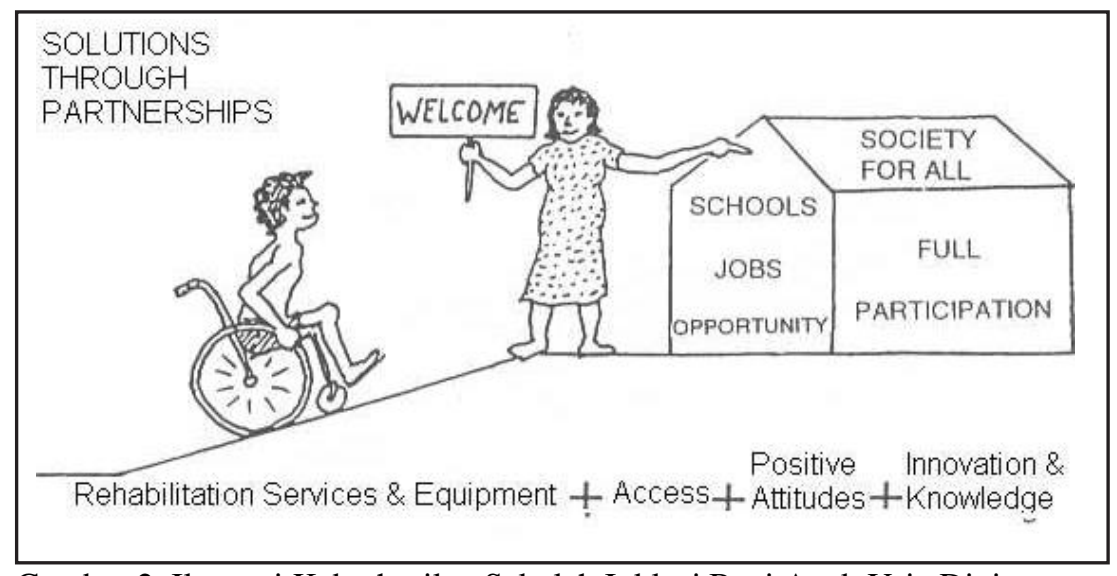

Gambar 2. Ilustrasi Keberhasilan Sekolah Inklusi Bagi Anak Usia Dini

\section{SIMPULAN DAN SARAN}

Model pendidikan inklusif berbasis authentic instructional model ini merupakan bentuk model yang mencoba untuk memberikan gambaran dalam menggabungkan prinsip akses pendidikan untuk semua pelajar ataupun individu yang kurang beruntung, dan tidak hanya untuk mereka yang berkebutuhan khusus. Oleh karena itu, hakikat utama dari model pendidikan inklusif ini merupakan pergeseran dari teori, asumsi, praktik, dan model khusus disabilitas ke sistem pendidikan inklusif yang bersifat spesifik non-disabilitas. Sehingga mampu meningkatkan pelaksanaan proses pendidikan inklusif lebih baik.

Saran dalam penulisan artikel ini adalah perlu adanya tindak lanjut terkait pengimplementasian pendidikan inklusif berbasis authentic instructional model di sekolah, seperti halnya adanya kerjasama yang optimal dari pemerintah dan seluruh lembaga pendidikan dalam penyelenggaraan pendidikan inklusif khususnya di sekolah reguler, serta diharapkan bagi setiap kepala sekolah, lembaga ataupun institusi pendidikan serta guru di sekolah untuk memahami pentingnya maksud serta tujuan dari penyelenggaraan pendidikan inklusif di sekolah reguler.

\section{ACKNOWLEDGMENT}

Kami ucapkan syukur kepada Allah SWT dan mengucapkan terima kasih kepada seluruh pihak dalam mendukung selama proses penyusunan penulisan ini.

\section{DAFTAR RUJUKAN}

Alfina, A., \& Anwar, R. N. (2020). Manajemen Sekolah Ramah Anak PAUD Inklusi. Jurnal Manajemen Pendidikan Islam, 4(1), 37.

Bhakti, C. P., Safitri, N. E., \& Rahman, F. A. (2018). Model Pendidikan Karakter Berbasis Integrated Learning Model Pada Pendidikan Anak Usia Dini. In Seminar Nasional dan Call for Paper "Membangun Sinergitas Keluarga dan Sekolah Menuju PAUD Berkualitas" (pp. 27-36).

Caraka, P. B., Fuad, A. R., \& Cecep, M. (2016). Peran Bimbingan Dan Konseling Dalam Implementasi Tarbiyah Project Untuk Meningkatkan Religiusitas Siswa. In Proceeding

Department of Education (DoE). (2010). Special needs education: Building an inclusive education and training system - special needs education. Education White Paper 6. Pretoria: Department of Education.

Fernandes, R. (2018). Adaptasi Sekolah Terhadap Kebijakan Pendidikan Inklusif. SOCIUS, 4(2), 119-125. 
Indriawati, P. (2013). Implementasi Kebijakan Tugas Guru Pembimbing Khusus pada Pendidikan Inklusif di SD Negeri se-Kecamatan Junrejo Batu. Jurnal Kebijakan dan Pengembangan Pendidikan, 1(1).

Johnson, Elaine. B. (2012). Contextual Teaching And Learning. Thousand Oaks: Corwin Press. Junanto, S., \& Kusna, N. A. A. (2018). Evaluasi Program Pembelajaran di PAUD Inklusi dengan Model Context, Input, Process, and Product (CIPP). INKLUSI, 5(2), 179-194.

Mittler, P. (2012). Working Towards Inclusive Education: Social Contexts. David Fulton Publishers.

Ni'matuzahroh. (2015). Analisis Kesiapan Guru dalam Pengelolaan Kelas Inklusi. Seminar Psikologi dan Kemanusiaan.

Permendiknas Nomor 70 Tahun 2009 tentang Pendidikan Inklusi bagi Peserta Didik yang Memiliki Kelainan dan Memiliki Potensi Kecerdasan dan/atau Bakat Istimewa

Peraturan Gubernur Banten Nomor 74 Tahun 2014 tentang Pedoman Penyelenggaraan Pendidikan Inklusif di Provinsi Banten

Savin-Baden, M., \& Howell-Major, C. (2013). Qualititative Research: The Essential Guide To Theory And Practice Maggi Savin-Baden And Claire Howell-Major.

Scott, K., et.al. (2010). Teacher attitudes toward increased mainstreaming: Implementing effective instruction for students with learning disabilities. Journal of Learning Disabilities, 28, 8794.

Sekolah Inklusi: Kurang Guru, Sekolah Inklusi Tolak Siswa Berkebutuhan Khusus. Diakses dari: http://www.solopos.com/2015/06/21/sekolah-inklusi-kurang-guru-sekolah-inklusi-tolaksiswa-berkebutuhan-khusus-616412, pada 03 Oktober 2019

Smith, J. David. (2014). Inklusi Sekolah Ramah untuk Semua. Bandung: Nuansa.

Stiawati, T. S. T., Listyaningsih, L., \& Aziizi, S. R. (2017). Implementasi Peraturan Gubernur Banten Nomor 74 Tahun 2014 Tentang Pedoman Penyelenggaraan Pendidikan Inklusif Di Provinsi Banten (Studi Pada Sekolah Inklusif Di Kota Serang). Jurnal Administrasi Publik, 8(1).

Tichá, Renáta and Abery, Brian and Johnstone, Christopher and Poghosyan, Alvard and Hunt, Paula. (2019). Inclusive Education Strategies: A Textbook. CBR NETWORK (South Asia) UN ECOSOC Special Consultative Status Associate Member, Rehabilitation International Undang-Undang Nomor 20 Tahun 2003 tentang Sistem Pendidikan Nasional

Wati, E. (2014). Manajemen Pendidikan Inklusi di Sekolah Dasar Negeri 32 Kota Banda Aceh. Jurnal Ilmiah Didaktika: Media Ilmiah Pendidikan dan Pengajaran, 14(2)

Windarsih, C. A., Jumiatin, D., Efrizal, E., Sumini, N., \& Utami, L. O. (2017). Implementasi Pendidikan Anak Usia Dini Inklusif Dikota Cimahi Jawa Barat. Jurnal Ilmiah P2M STKIP Siliwangi, 4(2), 7-11.

Zakia, D. L. (2015). Guru Pembimbing Khusus (GPK): Pilar Pendidikan Inklusi. Prosiding Ilmu Pendidikan, 1(2).

\section{AUTHOR}

Fuad Aminur Rahman, S. Pd merupakan seorang Guru Bimbingan dan Konseling di SMAN 1 Cihara. Pria kelahiran Tasikmalaya, 27 Juli Tahun 1996 memiliki hobi yaitu menulis, membaca dan bermain game

Acep Awaludin, M.Pd merupakan seorang Guru Bahasa Inggris di SMAN 1 Cihara, merupakan pria kelahiran Lebak, 10 Maret Tahun 1979 